\title{
REGENERATION PATTERNS IN A PEDUNCULATE OAK (QUERCUS ROBUR L.) STRICT FOREST RESERVE IN SOUTHERN HUNGARY
}

\section{PROCES POMLAEIVANJA HRASTA LUŽNJAKA (QUERCUS ROBUR L.) U STROGO ZAŠTIĆENOM ŠUMSKOM REZERVATU U JUŽNOJ MAĐARSKOJ}

\author{
Adrienne ORTMANN-AJKAI', Gábor CSICSEK², Márió LUKÁCS³, Ferenc HORVÁTH³
}

\begin{abstract}
Summary
Insufficient natural regeneration of pedunculate oak (Quercus robur L.) in alluvial hardwood forests is a serious problem both for close-to-nature silviculture and nature conservation, as it may lead to in-depth changes of forest structure. Natural regeneration processes in pedunculated oak forests are especially difficult to study due to the lack of strict forest reserves, where natural processes would be able to manifest. No-intervention (passive) conservation of closed floodplain pedunculate oak forests is often regarded as a failure not only of economic, but also of conservational point of view.

Our observations on spontaneous stand development of a floodplain pedunculate oak forest, including all woody species, were carried out in a strict forest reserve in Southern Hungary. Data on the current structure of a 120-years old stand, unmanaged for 17 years were sampled with the three-layer protocol of the Hungarian Forest Reserve Program, and analysed with PCA. Stand structure change was described by comparing current results with those of Braun-Blanquet releves from 1995-96. We presented a detailed case study of an unmanaged floodplain oak forest, and demonstrated that instead of regeneration of the closed Quercus robur-dominated high forest, forest-like stands of Crataegus monogyna developed. No-intervention conservation allowed natural processes to manifest, but not preserved local conservational values, and apparently did not sustain present, economically very valuable oak stands. Our results on the consequences of 17 years of passive conservation provide information useful for conservational decision-making.
\end{abstract}

KEY WORDS: Quercus robur, spontaneous dynamics, Crataegus monogyna community, strict forest reserve, passive conservation

\section{INTRODUCTION}

\section{UVOD}

Floodplain oak forests are among the most diverse ecosystems in Europe, both by structure and species composition.
They deserve special attention being the last remnants of "original nature" in densely populated areas (Leibundgut, 1993). As sources of high-quality timber, floodplain oak forests are under commercial management almost everywhere

\footnotetext{
${ }^{1}$ Adrienne Ortmann-Ajkai, Phd, Institute of Biology, University of Pécs, Ifjúság u.6., Pécs, Hungary, H-7624, e-mail: aadrienn@gamma.ttk.pte.hu*

2 Gábor Csicsek, Institute of Biology, University of Pécs, Ifjúság u.6., Pécs, Hungary, H-7624, csicsek@gamma.ttk.pte.hu

${ }^{3}$ Márió Lukács, e-mail: lukacs.mario@okologia.mta.hu, Ferenc Horváth, e-mail: horvath.ferenc@okologia.mta.hu, Institute of Ecology and Botany, Centre for Ecological Research of Hungarian Academy of Sciences, Alkotmány u.2-4, Vácrátót, Hungary, H-2163, e-mail:
} 
(FOREST EUROPE, 2015). They are especially endangered and almost disappeared (Leibundgut, 1993; Ellenberg 1996; Parviainen 2005; Matić et al., 2008). Due to outstanding economic value of oak forests, passive, no-intervention conservation faces huge difficulties. They are poorly represented in strict forest reserves networks (Diaci, 1999; Parvainen et al., 2000). Consequently there are rather few opportunities to study their natural dynamics, which makes the adaptation of close-to-nature forestry methods more difficult.

Hüttl et al. (2000) highlighted a lack of knowledge about dynamics of old-growth (semi)-natural forests. Unmanaged forests, regarded as best possible substitutes for natural forests, are popular objects of research (Brang, 2005). Strict forest reserves often have outstanding conservational value (Wesolowski, 2005) as they are biodiversity hotspots, important nature protection sites, considered consequently as conservation baselines (Schmidt, 2005) and as sources of reference data for close-to-nature silviculture (Parviainen et al., 2000). Such old-growth floodplain oak forests are e.g. the March-Thaya (Morava-Dyje) region in the AustrianBohemian-Slovak border (Hager et al. 2007 in Hobza 2007; Miklin and Cizek 2014); Prasnik, Stupnički Lug-Cret, Motovunska šuma, Loze and Radiševo, as „special forest reserves" in Croatia (Leibundgut, 1993, Matić 1999, Vukelic et al. 1999). More old-growth pedunculate oak stands („natural forests") are reported from Transcarpathian Ukraine (Drescher et al., 2003, and Roumania (Borlea, 1999 in Diaci, 1999). Network of strict forest reserves - by definiton: unmanaged forests -- in Germany consists of more than 700 reserves of 31000 ha; of this Ulmus-Alnus floodplain forest reserves cover only cca. 1000 ha; moist and mesophilous Quercus-Carpinus forests (not necessarily floodplain) cca. 1500 ha (Meyer et al., 2007).

Presumably the best-studied near-natural floodplain hardwood forests in Europe are situated in the March-Thaya (Morava-Dyje) wetland region, at the tristate border of Austria, Czech and Slovak republic, a set of unique forest ecosystems in Central Europe. Parts of it was declared as a Ramsar Site (Hager et al., 2007 in Hobza, 2007) and UNESCO Biosphere Reserve; it includes Ranspurk and Cahnov-Soutok strict forest reserves, woodland pastures and also other sites of Community Importance and Special Protection Areas (Miklin and Cizek, 2014). Its area is cca $200 \mathrm{~km}^{2}$, a cca 65 $\mathrm{km}$ long corridor along the rivers, down to the March-Danube confluence. Forests are mainly azonal floodplain forests within zonal Subpannonian mixed oak ones. The two largest continuous forest complexes are cca 1000 ha each. Main species are Quercus robur and Fraxinus angustifolia.

The Austrian part of the March-Thaya region has been studied since the 1970's. Wendelberger (1973) and Drescher (1985) published phytosociological studies on hardwood forests consisting of Quercus robur, Fraxinus angustifolia and Ulmus laevis, discussing also abiotic factors (flood dy- namics, soil characteristics), zonation and successional conditions which are very similar to our sites, as pointed out by Hager et al. (2007). Most of the oak stands are under high forest management with artificial regeneration, although coppice-with standards method is also used based on natural regeneration. On the contrary, Cahnov-Soutok National Natural Reserve, situated at the convergence of Dyje and Morava in the Czeh Republic, is left unmanaged since the 1930s. Whole-area measurement of stand structure had been executed in 1973 (Prusa, 1985). It was repeated in 1994 (Vrska, 1997), and 2006 (Janik et al., 2008; Král et al., 2014). Representation of Quercus robur decreased according to all monitored indicators (number of trees, basal area and volume); at the same time Acer campestre, Tilia cordata and Carpinus betulus increased. An expansion of Crataegus spp. among trees was also noted. A recent publication (Miklin and Cizek, 2014) reports on the perilous disappearance of old-growth forest stands, especially of open woodlands, contrary to conservational accreditations. According to this authors, closed canopy hinders oak regeneration, as closed forests were never naturally dominant in this region.

According to Leinbundgut's description, the Prašnik ,virgin forest" (Croatia, near the Sava river) has $40 \mathrm{~m}$ heigh upper canopy layer, dominated by Quercus robur (20-50 individuals/ha - at least partly forest-pasture). Many other species (Fraxinus angustifolia, Ulmus minor, Alnus glutinosa, Carpinus betulus, Acer campestre, Pyrus pyraster, Tilia cordata, T. tomentosa, Fagus sylvatica) occurs sporadically. In the middle and lower canopy layers there are less individuals (20-30/ha), because of the strong shading of wide-crowned oaks in the upper layer. In gaps formed by the death of old trees, dense, species rich (Crataegus monogyna and C. laevigata, Viburnum opulus, Prunus spinosa) shrub layer developed, but apparently it did not hinder oak regeneration (Leibundgut, 1993).

Dister (1985) presents an old-growth oak-ash forest from the upper Rhine, near Darmstadt. Its upper layer is $25-30 \mathrm{~m}$ high; consists mostly of Quercus robur of 150-190 years, low branching points to former coppice-with-standard management; and of some huge Fraxinus excelsior trees. In the lower levels Fraxinus dominates, due to its better regeneration and less sensitivity to game damage. Oaks are almost totally missing from the lower layers, but can be observed growing up in more enlight ened edges, protected by Crataegus.

Drescher et al. (2003) publishes three relevés from ,ancient” oak forests (160-170 years, but coppice-with-standards, except the Atak site) from the Upper Tisza floodplain (Northeastern Pannonian Plain, Transcarpathian Ukraine). Oak regeneration is not discussed explicitly, but Quercus robur is documented in the herb and shrub layer and also from second canopy. Our own unpublished data also prove natural regeneration of $Q$. robur in this geographic area.

Quercus robur is dominant native species of alluvial hardwood forests, but in closed stands it has a rather poor 
spontaneous regeneration potential. The phenomenon is documented in Hungary at the very beginning of $20^{\text {th }}$ century by Illés (1905) and by many other authors since that. Although seedlings may be abundant in the herb layer, they extremely rarely grow up into the shrub layer.

Quercus robur is a light-demanding species, this is why poor light conditions under closed canopy and in small-sized gaps hinder its regeneration (Miklin and Cizek, 2014; Annighöfer et al. 2015). An impressive amount of empirical evidence on the spontaneous regeneration of oaks in open or semi-open natural or anthropogenic landscapes, but not under closed stands, has been published by Vera (2000).

Browsing of too high game populations (Cervus elaphus, Capreolus capreolus) is also often-mentioned cause of insufficient oak forest regeneration (Hobza et al. 2007). High game populations may cause a change of stand structure not directly by oak damage, but with creating advantageous competition situation for less browsing-sensitive woody species, especially for thorny ones. The change of oldgrowth oak stands into thickets of shrubs had been largely overseen by researchers. Shrub species are usually excluded from forest structure studies; an exception is Tanentzap et al. (2012), who studied the interaction of deer browsing and survival of Crataegus and Corylus in the understorey of a mixed ash woodland.

Shrubs are documented in phytosociological works (e.g. Wendelberger, 1973; Drescher, 1985 and references therein), but usually only as a layer in the forest. Shrub communities of Crataegus monogyna (and Cornus sanguinea) are classified into Prunetalia spinosae order (Ellenberg, 1996; Borhidi, 2012), though being considered as an anthropogenic, temporary, degraded phase seldom phytosociologicaly studied in details. Kevey (1998) stresses that this issue should be investigated in more details and notes that they may be elements of natural vegetation dynamics. Thorny thickets, especially of Prunus spinosa and Crataegus monogyna protect juvenile oaks from browsing, so enable them to "grow out of the mouth of game": they are key elements of the shifting mosaic cycle of oak regeneration on the landscape scale (Vera, 2000).

\section{Knowledge gaps and research goals - Nepoznanice i ciljevi istraživanja}

Natural regeneration processes in pedunculate oak forests are especially difficult to study, due to the lack of strict forest reserves, where natural processes are able to manifest.

Existing studies describe stand structure with special attantion to Quercus robur, but seldom refer to other woody species. Our aim is thorough a detailed description of the stand structure of a floodplain Quercus robur strict forest reserve after 17 years of unmanagement, with special respect of mass regeneration of shrub species.

\section{MATERIALS AND METHODS} MATERIJAL I METODE

\section{Study area - Područje istraživanja}

Our study was performed in Bükkhát Forest Reserve, situated in the floodplain of Drava river (southern Hungary), in an elevation $96-100 \mathrm{~m}$ a.s.l.; GPS coordinates: N45 $52^{\prime} 43.83^{\prime \prime}$; $\mathrm{O} 18^{\circ} 00^{\prime} 28.27$ '. It is the largest floodplain oak forest reserve in Hungary with its area of 452 ha, declared as a forest reserve in 2002; but some parts are unmanaged since 1997. It has two strictly protected core areas of $58 \mathrm{ha}$, free of any kind of human intervention; and a buffer zone managed by closeto-nature silvicultural method (gap management), required by the Hungarian Forestry Act of 2009. Most stands are above 80 years, with a maximum of 120 years dominated by pedunculate oak (Quercus robur L.) high forest. The climate is moderately warm - moderately wet, mean annual temperature is $10.4^{\circ} \mathrm{C}$, mean annual precipitation is between 730 $760 \mathrm{~mm}$, with summer drought period occasionally up to two months. Soils are Histosols and Luvisols (FAO-UNESCO, 1997). Groundwater table is at 2-4 m (Dövényi, 2010). Depressions (former watercourse beds) are covered by water in springs up to three-six weeks. Dominant phytosociological associations are hornbeam-pedunculate oak forests (CircaeoCarpinetum Borhidi em. Kevey 2006), and nemoral floodplain forests of large rivers dominated by Fraxinus angustifolia Vahl (ass.A-8 in Douda et al., 2015) with Quercus robur, and Ulmus laevis Pall., (formerly known as oak-ashelm hardwood alluvial forests (Carici brizoidis-Ulmetum Kevey, 2008), with a transitional zone between them (OrtmannAjkai, 2002). The shrub layer is dense in the oak-ash, but may be missing in the oak-hornbeam stands. Characteristic herb species are: Circaea lutetiana L., Carex sylvatica Huds., C. remota L., Stachys sylvatica L., Pulmonaria officinalis L., Galium odoratum (L.) Scop., Rubus fruticosus agg. and R. caesius L. Both associations are natural habitats of European Community importance (NATURA 2000 habitats), listed as ,Riparian mixed forests of Quercus robur, Ulmus laevis and Ulmus minor Mill., Fraxinus excelsior or Fraxinus angustifolia, along the great rivers (Ulmenion minoris; 91F0)” and „Illyrian oak-hornbeam forests (Erythronio-Carpinion; 91L0)" (EC, 2007). For a more detailed description see also Ortmann-Ajkai (1998). Current even-aged stands originate from planting of pedunculate oak on clear-cut areas, intensively managed in the first years, then thinned in about tenyears periods, as usual in Hungary. No viable spontaneous regeneration of Quercus robur can be observed, although seedlings are abundant. The region is one of Hungary's most reputed red deer (Cervus elaphus) hunting area. Populations of red deer, and also of wild boar, are very high.

\section{Field sampling - Uzorkovanje}

Sampling was made in the 15 ha southern core area, in stands above 120 years, unmanaged since 1997. Vegeta- 
tion sampling was implemented in 2012, according to the Hungarian Forest Reserve Protocol (Horváth et al., 2012). A systematic 50x50 m grid of sampling points was permanently marked in the field ( 54 points in all). Three surveys have been carried out in each sampling points: of the tree stand structure, of the regeneration and shrub layer and of the herb layer. Tree layer survey included all individuals above $5 \mathrm{~cm}$ diameter at breast height (DBH) in a circle of $6,92 \mathrm{~m}$ radius $\left(250 \mathrm{~m}^{2}\right.$ area) plus those included in a horizontal point sampling $(\mathrm{DBH}>25.2 \mathrm{~cm}$, gauge constant $\mathrm{k}=2$; basal area factor $=2$ ). Species, $\mathrm{DBH}$, crown position compared to neighbouring trees, and health on a fivegrade scale were recorded for each individual tree. Survey of shrub and regeneration layer included individuals of all woody species above $50 \mathrm{~cm}$ height and under $5 \mathrm{~cm}$ diameter at soil surface. Eight sampling circles of $4 \mathrm{~m}^{2}(1.13$ $m$ radius), were surveyed at each sampling point, positioned systematically in $6 \mathrm{~m}$ distance around the centre. Species, height in two categories $(50-130 \mathrm{~cm}$ and above $130 \mathrm{~cm})$ and browsedness of the apical shoot $(\mathrm{Y} / \mathrm{N})$ were recorded for each individual rooting in the circles. Herb layer study was implemented in 30 circles of $0.5 \mathrm{~m}^{2}$ positioned systematically inside a circle of $6 \mathrm{~m}$ radius around the center of the sampling point. Cover of each herb species, and of woody species under $50 \mathrm{~cm}$ height were recorded on the Braun-Blanquet scale (Braun-Blanquet, 1928; cited in Whitaker, 1980). Stand height, cover of upper (A1) and lower (A2) crown layer, of shrub (B) and herb layer $(C)$ and gap size (four categories) were also recorded for all sampling points.

For the analysis of structural changes, data of 23 phytosociological releves were also included. Releves of $20 \times 20 \mathrm{~m}$ were made according to the Braun-Blanquet method in 1995-96 in the Bükkhát Forest reserve (Ortmann-Ajkai, 1998).

\section{Statistical analysis - Statističke analize}

Regeneration of seven woody species was analyzed trees: Quercus robur, Fraxinus angustifolia, Carpinus betulus L., Ulmus minor and Acer campestre L.; shrubs: Crataegus monogyna Jacq. and Cornus sanguinea $\mathrm{L}$.

Current stand structure, including vertical distributions, horizontal patchiness, gaps and some abiotic conditions, was characterized by principal component analysis (PCA) using CANOCO 4.55 (ter Braak \& Smilauer, 2002). Change of stand structure was analysed comparing current abundance data with those of 1995-96. Total cover of layers A1, A2, B and C, and specific cover values for Quercus, Crataegus and Rubus were obtained from 23 phytosociological releves. As data have no normal distribution, non-parametric Mann-Whitney u-tests were calculated, using PAST (Hammer et al., 2001).

\section{RESULTS}

REZULTATI

\section{Stand structure and change - Struktura sastojine i promjene}

As length of eigenvalues in a trial DCA implied linear data structure, PCA was selected for unconstrained ordination. Some structural characteristics of the study site are presented on the PCA scattergram (Figure 1). Majority of points represent hornbeam-oak stands (Circaeo-Carpinetum), characterized by Quercus robur in the upper and Carpinus betulus in the lower canopy and juveniles of Carpinus and Acer campestre in the shrub layer. There are many transitional points towards elm-ash stands (Carici brizoidis-Ulmetum). Some points characterised by Crataegus monogyna both in canopy and shrub layer, deviates from this broadly known situation.

The first two PCA axes accounts for 54\% variability (30/24\% respectively), all PCA axes for $79 ; 5 \%$. Species in the tree layer separate well along the first two axes into three groups. The hornbeam-oak - elm-ash continuum was represented along the first axis. Typical grove forest species (Fraxinus in A1 and A2; Ulmus and Cornus in A2) have high or medium positive scores on both axes $(0.20-0.56)$, while oak and hornbeam have both negative ones $(-0.58--0.19)$. Crataegus monogyna in A2 forms a separate group. Crataegus has the highest scores for both axes ( 0.70 and -0.70$)$, positive for the first but high negative for the second one. Carpinus betulus and Acer campestre in the shrub and herb layer also have high negative values on both axes, while juvenile individuals of grove forest species have lesser positive scores, Fraxinus even small negative ones. Note that juveniles of Quercus robur (in B2 and C) show remarkable positive values on Axis 2; characteristic of grove forest species (Figure 1).

The spontaneous stand development, creating this present structure, was characterized comparing data of 1995 and 2012 (Table 1). The most remarkable change is the increase of the total cover of the second canopy (from $27 \%$ to $54 \%$ ), and especially that of Crataegus monogyna (its total change from $2 \%$ to $14 \%$, its proportional change in the canopy is from $6 \%$ to $24 \%$ ). Cover of the shrub layer also has been increased to twofold ( $22 \%$ to $42 \%$ ), but proportions of the species have not changed significantly. Cover of herb layer is high (about $80 \%$ ) at both times, but cover of the regrowth of the seven studied woody species decreased from $12 \%$ to $4 \%$. At the same time, cover of Crataegus monogyna in the herb layer has risen to sixfold (although only $0,4 \%$ even now), and that of Rubus with $45 \%$. All these results are significant at $\mathrm{p}=0,01$. Other changes see in Table 1 .

\section{DISCUSSION RASPRAVA}

PCA scattergram (Figure 1) partly presents a characteristic picture of floodplain oak forests of Hungary, well-known 
Table 1. Changes in cover of different structural layers and of selected plant species in the period of 1995-2012 (significant changes are indicated in bold).

Tablica 1. Promjene pokrovnosti različitih slojeva i odabranih biljnih vrsta u razdoblju od 1995-1912 (signifikantne promjene su označene podebljanim bold pismom).

\begin{tabular}{|c|c|c|c|c|c|c|c|c|c|c|}
\hline & \multicolumn{4}{|c|}{$\begin{array}{l}1995 \text { (23 samples) } \\
1995 \text { (23 uzorka) }\end{array}$} & \multicolumn{4}{|c|}{$\begin{array}{l}2012 \text { (54 samples) } \\
2012 \text { (54 uzorka) }\end{array}$} & \multicolumn{2}{|c|}{$\begin{array}{l}\text { Change } \\
\text { Promjene }\end{array}$} \\
\hline & $\begin{array}{l}\text { Average } \\
\text { Sredina }\end{array}$ & $\begin{array}{l}\text { Min } \\
\text { Min }\end{array}$ & $\begin{array}{l}\text { Max } \\
\operatorname{Max}\end{array}$ & $\begin{array}{l}\text { Std } \\
\text { Std }\end{array}$ & $\begin{array}{l}\text { Average } \\
\text { Sredina }\end{array}$ & Min & Max & Std & $\mathrm{p}$ (same) & '12/'95 \\
\hline $\begin{array}{l}\text { Cover of upper canopy (A1) } \\
\text { Pokrovnost gornjeg sloja krošnji (A1) }\end{array}$ & 66.6 & 30 & 100 & 17.92 & 69.9 & 45 & 90 & 21.42 & ns & 1.05 \\
\hline $\begin{array}{l}\text { Cover of lower canopy (A2) } \\
\text { Pokrovnost donjeg sloja krošnji (A2) }\end{array}$ & 27.1 & 0 & 80 & 18.49 & 54.5 & 5 & 80 & 17.72 & $\mathrm{p}<<0.01$ & 2.01 \\
\hline $\begin{array}{l}\text { Cover of Crataegus in A2 } \\
\text { Pokrovnost gloga u A2 }\end{array}$ & 1.9 & 0 & 25 & 5.57 & 13.9 & 0 & 63 & 15.30 & $\mathrm{p}<<0.01$ & 7.32 \\
\hline $\begin{array}{l}\text { Proportion of Crataegus in A2 (\%) } \\
\text { Udio gloga u A2 (\%) }\end{array}$ & 6.22 & 0 & 83 & 18.79 & 24.4 & 0 & 90 & 23.11 & $\mathrm{p}<<0.01$ & 3.92 \\
\hline $\begin{array}{l}\text { Cover of shrub layer (B) } \\
\text { Pokrovnost sloja grmlja (B) }\end{array}$ & 21.8 & 1 & 65 & 21.26 & 42.4 & 2 & 90 & 22.14 & $\mathrm{p}<<0.01$ & 1.94 \\
\hline $\begin{array}{l}\text { Cover of Crataegus in B } \\
\text { Pokrovnost gloga u B }\end{array}$ & 2 & 0 & 10 & 2.97 & 4.1 & 0 & 19.6 & 4.88 & $\mathrm{p}<<0.01$ & 2.05 \\
\hline $\begin{array}{l}\text { Proportion of Crataegus in B (\%) } \\
\text { Udio gloga u sloju B }\end{array}$ & 10.9 & 0 & 80 & 18.71 & 9.8 & 0 & 41 & 10.30 & ns & 0.90 \\
\hline $\begin{array}{l}\text { Cover of herb layer (C) } \\
\text { Pokrovnost zeljastog sloja (C) }\end{array}$ & 84.9 & 27 & 156 & 32.31 & 79.8 & 8 & 276 & 52.56 & ns & 0.94 \\
\hline $\begin{array}{l}\text { Cover of selected woody species in C } \\
\text { Pokrovnost odabranih vrsta drveća u sloju C }\end{array}$ & 11.7 & 0 & 82 & 16.76 & 3.9 & 0.2 & 11 & 2.45 & $p=0.005$ & 0.33 \\
\hline $\begin{array}{l}\text { Cover of Crategus in C } \\
\text { Pokrovnost gloga u C }\end{array}$ & 0.06 & 0 & 0.5 & 0.14 & 0.4 & 0 & 4.9 & 0.77 & $\mathrm{p}<<0.01$ & 6.67 \\
\hline $\begin{array}{l}\text { Cover of Quercus in C } \\
\text { Pokrovnost hrasta } u \text { C }\end{array}$ & 0.27 & 0 & 0.5 & 0.24 & 0.13 & 0 & 0.6 & 0.14 & ns & 0.48 \\
\hline
\end{tabular}
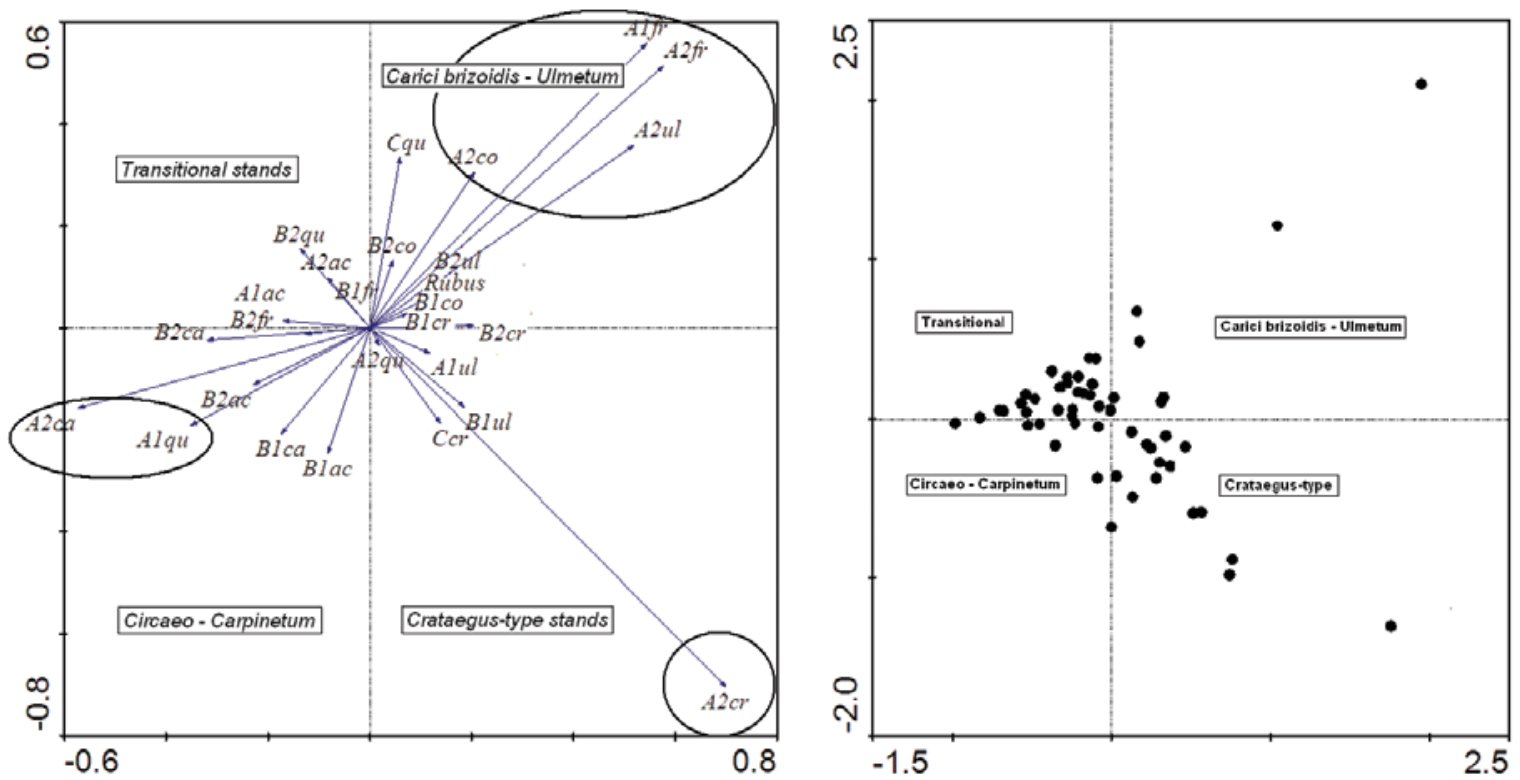

Figure 1. Forest structure displayed on PCA scattergram. a. Species in tree and shrub layer, separate three canopy types; b. Distribution of sampling points displays a continuum between oak-hornbeam and oak-ash-elm stands, known from phytosociology; some points, characterised by Crataegus both in canopy and shrub layer, deviates from this "classic" picture. Codes indicate structural layers (A1, A2: upper and lower canopy; B1, B2: upper and lower shrub layer; C: herb layer) and species: ac: Acer campestre, ca: Carpinus betulus, co: Cornus sanguinea, cr: Crataegus monogyna; fr: Fraxinus angustifolia, qu: Quercus robur, ul: Ulmus minor.

Slika 1. Struktura šumskih sastojina prikazana je na PCA dijagramu. a. Vrste u sloju drveća i grmlja, posebni tipovi krošnje drveća b. Raspored točaka uzorkovanja prikazuje neprekidan niz između sastojina hrastovo-grabovih šuma i sastojina šuma lužnjaka, jasena i brijesta, što je potvrda poznate fitocenološke pravilnosti; neke točke sa glogom (Crataegus) u sloju drveća i u sloju grmlja odstupaju od poznate šeme. Oznake za strukturne slojeve (A1, A2: gornji i donji sloj krošnje; B1, B2 gornji i donji sloj grmlja; C: sloj zeljastog bilja) i vrste: ac: Acer campestre, ca: Carpinus betulus, co: Cornus sanguinea, cr: Crataegus monogyna; fr: Fraxinus angustifolia, qu: Quercus robur, ul: Ulmus minor. 
from phytosociological works, which are based on phytosociological releves made in high oak forest stands. The gradual transition between closed hornbeam-oak stands on drier sites, and more lighted and more wet-demanding oakash-elm phytosociological units, described by OrtmannAjkai (2002) are well recognisable.

The more interesting part of our results is what they say about spontaneous forest dynamics, especially of the regeneration of Quercus robur, as these processes build the base for close-to-nature silviculture (Brang, 2005). According to the gap dynamics theory, regeneration takes place in spontaneous gaps in old stands, due to the more favourable light conditions. In our case, oak regeneration also seems to work better in more grove-forest like stands, i.e. in sites with better light and moisture conditions, supporting results of e.g. Vera (2000), Küssner (2003) in Germany, Čater and Batič (2006) in Slovenia, Ostrogović et al., 2010 in Croatia, Terwei et al (2013) in Italy. The destructive effects of groundwater table drop on floodplain oak forests in Croatia were discussed in details by Prpič (2008). Physiological studies of Škvorc et al. (2012) prove that oaks growing on soils with a higher nutrient content has higher intensity of photosynthesis, consequently better growth.

At the same time, Quercus robur seedlings are very scarce both in managed, and also in unmanaged stands (Table 1), supporting findings of many authors (Illés, 1905; Leibundgut, 1993; Prusa, 1985; Vrska, 1997; Janik et al., 2008; Král et al., 2014). A distinct difference of species composition of tree and regeneration layers is demonstrated, parallel to improved light conditions: a strong decrease in Quercus robur and rise of more pioneer species, e.g. Fraxinus angustifolia, and shrub species as Crataegus monogyna and Cornus sanguinea. Some sampling points, characterised by Crataegus monogyna dominance especially in the second canopy, deviate from the high forest structure. In gaps, providing better light conditions, usual mesophilous or wet-demanding species of floodplain hardwood forests, Fraxinus angustifolia, Carpinus betulus, Acer campestre and Ulmus laevis regenerate. Crataegus monogyna also appear in the second canopy, and with a proportion of almost $25 \%$. On the longer run, when old trees of the upper canopy fall, a vegetation type dominated by Crataegus monogyna may appear. Apparently, spontaneous stand development lead from a closed oak-hornbeam-ash high forest towards a gapfragmented mosaic with dense Crataegus stands.

Crataegus shrubs, widespread and well-known elements of vegetation, mentioned only superficially in syntaxonomical works (Ellenberg, 1996; Borhidi, 2012), as secondary, evolving on margins and on unmanaged grasslands, as a stage of spontaneous reforestation (Kevey, 1998). The idea of "cyclic succession mosaic" is thoroughly developed by Vera (2000), who also cites an impressive amount of case studies on closed oak stands opening up, then self-regenerating in a longer run, through a thorny shrub phase, where juvenile oaks found protection against game browsing.

Our results raise attention to the fact that different natural forests can be characterized by different types of natural dynamics (Bengtsson et al., 2000). Continuos cover forestry is less conducive to species of high light demand (Gamborg and Larsen, 2003), like Quercus robur. Light-demanding species need larger gaps for their regeneration, created by windstorms or fire, but these factors are not common in our floodplains. Another possibility is that open spaces were created by the hydrogeomorphic dynamics of natural floodplains, but these processes do not work any more in regulated floodplains. The Vera hypothesis offers an alternative. Its key element - protection of oak regeneration by natural thorny shrubs - may be worth to consider to be utilized in close-to-nature forestry practice.

\section{CONCLUSIONS}

\section{ZAKLJUČCI}

Our results draw the attention to the necessity of reconsidering the intertwining issues of spontaneous forest dynamic processes, naturalness, conservational values, and closeto-nature silviculture. Main aim of recent forestry is the economic and sustainable management of forests. Close-tonature forest management creates forests of remarkable conservational values. At the same time, no-intervention conservation allows natural forest dynamics to realize, so it may lead to more natural stands, with less economic, but with other kinds of conservational values: exceptional forest types, new kinds of habitats, higher biodiversity, unique research possibilities. Finding a proper equilibrium between managed and unmanaged forests, providing the highest landscape-level diversity is the responsibility of all decisionmakers in any sectors dealing with forests.

\section{ACKNOWLEDGEMENT ZAHVALA}

Authors express gratitude to local foresters, especially E. Burián, T. Molnár, A. Pyber and I. Várady for help in fieldwork. Students of the UP, R. Hollós, V. Magyaros, E. Rogács, V. Sass, D. Varga-Tiffán and A. Vida essentially contributed to fieldwork. We are grateful to Dragica Purger for the Croatian translation and also correcting the English text.

\section{REFERENCES}

\section{LITERATURA}

- Annighöfer, P., P. Beckschäfer, T. Vor, C. Ammer, 2015: Regeneration patterns of European oak species (Quercus petraea (Matt.) Liebl., Quercus robur L.) in dependence of environment and neighborhood. PLoS ONE 10(8): e0134935. doi:10.1371/ journal.pone.0134935 
- Bengtsson, J., Nilsson, S.G., Franc, A. and Menozzi, P. 2000. Biodiversity, disturbances, ecosystem function and management of European forests. Forest Ecology and Management, 132, 3950.

- Borhidi, A., B. Kevey, G. Lendvay, 2012: Plant communities of Hungary. Akadémiai, pp.610, Budapest

- Borlea, G.F, 1999: Forest reserves and their research in Romania. In: Diaci, J (ed), 1999: Virgin forests and forest reserves in Central and East European countries. History, present status and development. pp. 67-86.

- Brang P, 2005: Virgin forests as a knowledge source for Central European silviculture: reality or myth? For Snow Landsc Res 79(1/2): 19--3

- Braun-Blanquet J,, 1928: Pflanzensoziologie, Grundzüge der Vegetationskunde. Springer, pp.330, Berlin

- Čater M, F. Batič, 2006: Groundwater and light conditions as factors in the survival of pedunculate oak (Quercus robur L.) seedlings. Eur J Forest Res 125: 419-426

- Diaci, J (ed), 1999: Virgin forests and forest reserves in Central and East European countries. History, present status and development. Ljubljana, pp. 172.

- Dister, E., 1985: Zur Struktur und Dynamik alter hartholzauenwalder (Querco-Ulmetum Issl.24) am nördlichen Oberrhein. Verh. Zool.-Bot. Ges. Österreich 123(1985): 13-22.

- Douda J, K. Boublik, M. Slezák, I. Biurrun, J. Nociar, A. Havrdova, J. Doudova, S. Acic, H. Brisse, J. Brunet, et al., 2015: Vegetation classification and biogeography of European floodplain forests and alder carrs. Appl Veg Sci 19: 147-163.

- Dövényi, Z. (ed), 2010: Magyarország kistájainak katasztere. (Inventory of micro-regions of Hungary). 2nd ed. (revised). Hungarian Academy of Sciences. 876 pp

- Drescher, A. 1985: Die südostmitteleuropaischen Hartholzauenwalder - Ein Vergleich. Verh. Zool.-Bot. Ges. Österreich 123(1985): 33-42.

- Drescher, A, B. Prots, O. Mountford, 2003: The world of old oxbowlakes, ancient riverine forests and drained mires in the Tisza river basin. International excursion to Eastern Hungary and Transcarpathia, Ukraine 31.08.-04.09.2002. Fritschiana Graz 45: 43-69.

- Ellenberg, H., 1996: Vegetation Mitteleuropas mit den Alpen in ökologischer, dynamischer und historischer Sicht. Ulmer, Stuttgart, pp.1095.

- Gamborg, C., Larsen, J.B., 2003. 'Back to nature' - a sustainable future for forestry? Forest Ecology and Management, 179, 559571.

- FAO-UNESCO, 1997: Soil map of the world. Technical paper 20, ISRIC, Wageningen, pp.146

- FOREST EUROPE, 2015: State of Europe's Forests 2015. Ministerial Conference on the Protection of Forests in Europe, pp. 314.

- Hager, H., H. Schume, H. Tiefenbacher, E. Buchleitner, 2007: The management of floodplain forests in Austria. In: Hobza P (ed), 2007. Forest management systems and regeneration of floodplain forest sites. Reviewed proceedings from the international conference. Mendel University of Agriculture and Forestry, Brno, pp. 41-60.

- Hammer Ø, D.A.T. Harper, P.D. Ryan, 2001: PAST: Paleontological Statistics Software Package for Education and Data Analysis. Palaeontol Electron 41: 9
- Hobza P (ed), 2007: Forest management systems and regeneration of floodplain forest sites. Reviewed proceedings from the international conference. Mendel University of Agriculture and Forestry, Brno, ISBN 978-80-7375-089-3; pp.242.

- Hobza, P., O. Mauer, P. Fibich, D. Jirman, 2007: Effect of size of regeneration elements (clearcut areas) on the growth of pedunculate oak (Quercus robur L.) in artificial regeneration. In: Hobza, P. (ed., 2007): Forest management systems and regeneration of floodplain forest sites. Reviewed proceedings from the international conference, pp. 75-88.

- Horváth F, A. Bidló, B. Heil, G. Király, B. Kovács, G. Mányoki, K. Mázsa, E. Tanács, G. Veperdi, J. Bölöni, 2012: Abandonment status and long-term monitoring of strict forest reserves in the Pannonian biogeographical region. Plant Biosyst 146: 189-200

- Hüttl R.F., U. Schneider, E.P. Farrell, 2000: Forests of the temperate region: gaps in knowledge and research needs. For Ecol Manage 132:83-96

- Illés N., 1905: A tölgyesek kiképzéséről. (On regeneration of oaks). Erdészeti Lapok 44: 293-301. In Hungarian.

- Janik, D., D. Adam, T. Vrska, L. Hort, P. Unar, K. Kral, P. Samonil, D. Horal, 2008: Tree layer dynamics of the Cahnov-Soutok nearnatural floodplain forest after 33 years 1973-2006. Eur J Forest Res 127: 337-345.

- Kevey, B., 1998: A Szigetköz erdeinek szukcessziós viszonyai. (Succession in forests of Szigetköz). Kitaibelia 3:47-63. with German abstract

- Kevey, B., 2008: Magyarország erdőtársulásai. (Forest communities of Hungary). Tilia 14, Sopron, pp.488 In Hungarian.

- Král K, M. McMahon, D. Janik, D. Adam, T. Vrska, 2014: Patch mosaic of developmental stages in central European natural forests along vegetation gradient. Forest Ecol Manag 330: 17-28.

- Küssner R., 2003: Mortality patterns of Quercus, Tilia and Fraxinus germinants in a floodplain forest on the river Elbe, Germany. Forest Ecol Manag 173: 37-48.

- Leibundgut, H., 1993: Europäische Urwälder, Wegweiser zur naturnahen Waldwirtschaft. Haupt, pp.260.

- Matić, S., 1999: The forests of Croatia - country report. In: Diaci, J. ed.,1999: Virgin forests and forest reserves in Central and East European countries. History, present status and development. Ljubljana, pp. 17-23.

- Matić S, M. Anić, M. Orsanić, 2008: Forest management in floodplain forests. In: Klimo, E., Hager, H., Matić, S., Anić, I., Kulhavy, J. (eds): Floodplain forests of the temperate zone of Europe, pp. 231-283.

- Miklin J., L. Cizek, 2014: Erasing an European biodiversity hotspot: Open woodlands, veteran trees and mature forests succumb to forestry intrensification, succession and logging in a UNESCO Biosphere Reserve. J Nat Conserv 22: 35-41

- Meyer, P., W. Bücking, U. Gehlhar, U. Schulte, R. Steffens, 2007: Das Netz der Naturwaldreservate in Deutschland: Flachenumfang, Representativet and Schutzstatus im Jahr 2007. Forstarchiv 78: 188-196.

- Ortmann-Ajkai, A., 1998: Vegetation mapping as a base of botanical GIS applications II: Vegetation map of Vajszló forest SW Hungary. Acta Bot Hung 41(1-4): 171-192

- Ortmann-Ajkai, A., 2002: Transitory vegetation types, a case study from riverine forests. Acta Bot Hung 44: 335-346

- Ostrogović, M. Z., Sever, K., Anić, I., 2010: Utjecaj svjetla na prirodno pomlađivanje hrasta lužnjaka (Quercus robur L.) u 
park-šumi Maksimir u Zagrebu - Influence of light on natural regeneration of pedunculate oak (Quercus robur L.) In the Maksimir forest park in Zagreb

- Parviainen, J., 2005: Virgin and natural forests in the temperate zone of Europe. For Snow Landsc Res 78(1/2): 9-18

- Parvianinen, J., W. Bücking, K. Vanderkhoeve, A. Schuck, R. Paivinen, 2000: Strict forest reserves in Europe: efforts to enhance biodiversity and research on forests left for free development in Europe EU-COST Action E4. Forestry 73:107-118

- Prpič, B., 2008: Undesirable hydrotechnical impacts upon Croatian floodplain forests. In: Klimo, E., Hager, H., Matić, S., Anić, I., Kulhavy, J. (eds): Floodplain forests of the temperate zone of Europe, pp. 50-65.

- Prusa, E., 1985: Die böhmischen und mährischen Urwälder Ihre Struktur und Ökologie. Academia, Praha.

- Schmidt, W., 2005: Herb layer species as indicators of biodiversity of managed and unmanaged beech forests. For Snow Landsc Res 79:111-125

- Škvorc, Ž., Sever K., Franjić, J., Krstonošić, D., Poljak, M., 2012: Intenzitet fotosinteze i vegetativni rast hrasta lužnjaka (Quercus robur L.) u pokusnom nasadu (Photosynthesis intensity and vegetative growth of pedunculate oak (Quercus robur L.) in common-garden experiment. Sumarski List 86: 7-17

- Tanentzap, A.J., E.P. Mountford, A.S. Cooke, D.A. Coomes, 2012: The more stems the merrier: advantages of multi-stemmed architecture for the demography of understory trees in a temperate broadleaf woodland. Journal of Ecology 100:171-183.

- ter Braak, C.J.F., L. Smilauer, 2002: CANOCO reference manual and CanoDraw for Windows user's guide, software for canonical community ordination version 4.5. Biometris-Plant Research International, Wageningen

- Terwei, A., S. Zerbe, A. Zeileis, P. Annighöfer, H. Kawaletz, I. Mölder, C. Ammer, 2013: Which are the factors controlling tree seedling establishment in North Italian floodplain forests invaded y non-native tree species? Forest Ecol Manag 304:192-203

- Vera, F.W.M., 2000: Grazing ecology and forest history. CABI publishing, pp 505.

- Vukelić, J., Barićević, D., Perković, Z. 1999: Vegetacijske I druge znaćajke zastićenog dijela "Slatinskih Podravskjih suma” - Vegetative and other characteristics of the protected part of "Slatinske Podravske Sume”. Šumarski List 73: 287-289

- Vrska, T., 1997: Prales Cahnov po 21 letech. Lesnictvi - Forestry 43: 155-180.

- Wendelberger, G., 1973: Überschwemmte Hartholzauen? Vegetatio 28 (5-6):253-281.

- Wesolowski, T., 2005: Virtual conservation: How the European Union is turning a blind eye to its vanishing primeval forests. Conserv Biol 19:1349-1358

- Whitaker, R.H. (ed), 1980: Classification of Plant Communities. Junk Publishers, The Hague, Boston, London. pp

\section{Sažetak}

Nedovoljno uspješno prirodno pomlađivanje hrasta lužnjaka Quercus robur L. u poplavnim šumama velik je problem i za šumarsku proizvodnju, kao i za zaštitu prirode, jer dovodi do značajnih promjena u sastavu šuma. Pasivna zaštita poplavnih lužnjakovih šuma zatvorenog sklopa pokazala se neuspješnom ne samo s ekonomskog stajališta, nego i sa stajališta zaštite šuma. Najveća prepreka istraživanju prirodnog pomlađivanja lužnjakovih šuma je nedostatak strogih šumskih rezervata u kojima se očituju prirodni procesi. Naša istraživanja provedenasu u strogom rezervatu u južnoj Mađarskoj, a zapažanja o razvoju hrastovih šuma uključila su sve vrste drveća. Sadašnja struktura sastojine stare 120 godina, koja se spontano razvijala prethodnih 17 godina uzorkovana je prema Državnom Protokolu za Šumske Rezervate, a podaci su statistički analizirani pomoću metode osnovnih komponenti (PCA). Promjene strukture sastojina opisane su na temelju usporedbe sadašnjeg stanja i stanja koje je zabilježeno u fitocenološkim snimkama po Braun-Blanquet-u iz 1995-96. godine. Uz detaljne studije sastojine poplavne lužnjakove šume, predstavili smo i proces pomlađivanja šume zatvorenog sklopa s dominacijom lužnjaka te sastojine gloga Crataegus monogyna koja ima izgled šume u početnoj razvojnoj fazi. Naši rezultati dobijeni su na temelju analize pasivne zaštite šuma tijekom 17 godina, potvrdili su da zaštita šuma bez ikakvih intervencija pomaže ostvarivanju prirodnih procesa, ali ne i očuvanju lokalnih prirodnih vrijednosti, niti obnavljanju ekonomski vrijednih sastojina hrasta lužnjaka, a zaključci mogu biti korisni pri donošenju odluka vezanih za zaštitu prirode.

KLJUČNE RIJEČI: Quercus robur, spontana dinamika, zajednica Crataegus monogyna, strogi šumski rezervat, pasivna zaštita 